\title{
Analysis and Monitoring of Small-Scale Rock Fracture Zone Deformation and Shaft Failure in a Metal Mine
}

\author{
Rong Lu $\mathbb{D}$, ${ }^{1,2}$ Fengshan Ma $\mathbb{D}^{1},{ }^{1}$ Jie Zhao $\mathbb{D}^{2},{ }^{2}$ Jianbo Wang $\mathbb{D}^{2},{ }^{2}$ Guilin Li $\mathbb{D},{ }^{2}$ and Bing Dai $\mathbb{C}^{3}$ \\ ${ }^{1}$ Key Laboratory of Shale Gas and Geoengineering, Institute of Geology and Geophysics, Chinese Academy of Science, \\ Beijing 100029, China \\ ${ }^{2}$ Deep Mining Laboratory Subsidiary of Shandong Gold Mining Technology Co. Ltd., Jinan 250101, China \\ ${ }^{3}$ Nuclear Resource Engineering College, University of South China, Hengyang, China \\ Correspondence should be addressed to Fengshan Ma; fsma@mail.iggcas.ac.cn
}

Received 26 May 2020; Revised 23 July 2020; Accepted 5 August 2020; Published 3 September 2020

Academic Editor: Wen-Chieh Cheng

Copyright (c) 2020 Rong Lu et al. This is an open access article distributed under the Creative Commons Attribution License, which permits unrestricted use, distribution, and reproduction in any medium, provided the original work is properly cited.

\begin{abstract}
Rock fracture zones were distributed in a metal mine, and their deformation was always neglected because they are available on a small scale. However, the deformation of the small-scale fracture zone may lead to serious consequences, such as underground building and structure failure. Combined with the ground movement and surface fissure monitoring, the deformation of several fracture zones was analyzed by field monitoring, experimental test, and numerical simulation. The results showed that fracture deformation promoted the surface fissure movement. The horizontal movement of the foot wall rock of the fracture was found to be larger than the hanging wall rock. Deep mining engineering resulted in the squeezing of the shallow fracture, and the shallow fracture deformed more severely than the deep fracture. In the study area, fracture zone displacements were estimated according to a numerical model. The deformation and stress comparison of the shallow fracture zone and the deep fracture zone provided the characteristic of the broken structure in the field investigation.
\end{abstract}

\section{Introduction}

The cut and backfill mining technology has been used in many metal mines with rapid progress. Initially, it was generally believed that the cut-and-fill mining method could effectively control the ground pressure and prevent the development of ground deformation and ground fissure [1-3]. However, some metal mines that used this mining method observed ground fissure and ground subsidence pheromone during mining over the decades. Although backfill provides support to the surrounding rock mass and restrains its deformation, the mining also induces the rock mass movement and ground subsidence.

For the study of the rock mass movement and ground subsidence, Fengshan et al. set the monitoring network to record the ground movement in the Jinchuan mine and analyzed the monitoring data and confirmed a subsidence center [4]. For studying the subsidence evolution in the metal mine, Xin et al. analyzed the frequency-size distribution of ground movement evolution [5]. Rong et al. combined monitoring points and underground backfill to analyze the rock movement influenced by the backfill deformation [6].

Besides ground subsidence, mining engineering also induced the major fault reactive in the mining area. Haijun et al. studied F16 in the reactivation and deformation of the Jinchuan mine [7]. Kuo et al. investigated the fault movement induced by mining stope roof deformation in the mining process [8]. Researchers have paid attention to the deformation of the open-pit rock after the transition to underground mining [9-14]. It has become an important research area to explore the fault reactive caused by excavation. Some researchers have also studied the patterns of the differential settlement result from the fault in the mining situation [15-19].

The rock mass movement in the mine could lead to some damages to shafts, buildings, roads, and other facilities. Islam and Sherman evaluated the building damage 
influenced by the fault reactive caused by excavation [19]. The mechanism of the rock mass movement influenced by the fault was studied, and the reasons of ground fissures that occurred were analyzed.

Based on the above studies, the ground subsidence centers are found to be located on the hanging side of the ore body in the mine. The rock mass of the hanging wall can more easily move as compared to the foot wall. It was concluded that the foot wall rock mass is stable. Based on this concept, some mining facilities, structures, and buildings were set on the foot wall area in the mine. However, the rock mass in the foot wall contains some rock fracture zones with a small-scale and slow inclination. Some fracture zones were found to be severely broken. The mining influence of rock fracture zones was more obvious with an increase in the mining depth. The deformation of fracture zones resulted in some broken buildings and structures in the mining area. So, the rock fracture zones in the deformation and movement of the foot wall area are also considered vital in mining engineering.

\section{Background of the Study Area}

2.1. Overview of the Study Area. In China, the Jinchuan mine is the largest nickel mine. The mine deposit is about $6,500 \mathrm{~m}$ long, $200 \mathrm{~m}$ wide, and over $1,000 \mathrm{~m}$ deep, as shown in Figure 1(a). The native ore-bearing rocks are divided into four independent fields due to the major faults, as shown in Figure 1(b). The major study area in this article is the No.1 ore body attributed to the No.2 mining zone.

The backfill mining method helped in maintaining the overall stability of the Jinchuan mine during mining over the decades. However, ground subsidence and overlying rock mass movement occurred. The first fissure was observed in 2001, and in the same year, the monitoring points were set for the monitored displacement period. After nearly two decades of monitoring work, the subsidence center was found that was located in the hanging wall rock mass. The displacements of the hanging wall rock mass were found to be larger than the foot wall rock. The foot wall rock was observed to be basically stable. So, some structures were built in the foot wall area. However, the ventilating shaft located in the foot wall area was damaged. Investigation showed that the shaft went through several rock fracture zones. The deformation of the fracture zones resulted in the shaft damage.

\subsection{Rock Fracture Zones and Ventilating Shaft Situation.}

The rock fracture zones were distributed in the profile of exploration line-14, and the surface elevation of exploration line-14 is approximately $1730 \mathrm{~m}$. The profile map is shown in Figure 2. In this profile, more than five fracture zones were investigated, and the ventilating shaft went through these zones. From shallow to deep, the burial depths of these fracture zones are as follows: the burial depths of fracture zone 1 are -150 to $-200 \mathrm{~m}$ (the corresponding elevation is $1580 \mathrm{~m}$ to $1530 \mathrm{~m}$ ); the burial depths of fracture zone 2 are -220 to $-280 \mathrm{~m}$ (the corresponding elevation is $1510 \mathrm{~m}$ to
$1450 \mathrm{~m}$ ); the burial depths of fracture zone 3 are -370 to $-400 \mathrm{~m}$ (the corresponding elevation is $1360 \mathrm{~m}$ to $1330 \mathrm{~m}$ ); the burial depths of fracture zone 4 are -480 to $-530 \mathrm{~m}$ (the corresponding elevation is $1250 \mathrm{~m}$ to $1200 \mathrm{~m}$ ); and the burial depths of fracture zone 5 are -580 to $-630 \mathrm{~m}$ (the corresponding elevation is $1150 \mathrm{~m}$ to $1100 \mathrm{~m}$ ). All these fracture zones are available in a small scale. Some fracture zones are gently inclined. The ventilating shaft was repaired after damage, and two cracks were observed on the wall of the shaft.

The major failure part was located on $-170 \mathrm{~m}$ of the ventilating shaft. The shaft is seated in the scope of the depression induced by the underground mining, and displacement of the rock mass keeps increasing. The rock mass movement, rupture, and fall are the primary forms of the shaft deformation, and the fracture effects will be aroused again in the future under the present circumstances of mining. For the ventilating shaft, the rock rupture in the shallow part is more serious than the deep part.

\section{Analysis of Ground Subsidence and Fissures in Exploration Line-14}

For the problem of ground subsidence and fissures, 124 monitoring points were set, which gradually covered the entire mining area in 2001. The monitoring period was half a year. Based on the monitoring data, the characteristics of the ground subsidence and fissures of exploration line-14 were analyzed.

\subsection{Ground Subsidence Analysis of Exploration Line-14.} The monitoring work was performed for almost 20 years, and the subsidence basin evolved gradually. The distribution of the monitoring points is shown in Figure 3(a). The subsidence center is $340 \mathrm{~m}$ away from the ventilation shaft on exploration line-14 and $130 \mathrm{~m}$ away from the projection of the ore body on the surface. Monitoring point 1407, as the subsidence center, recorded the maximum vertical displacement (Figure 3(a)). The subsidence center was found on the hanging wall rock mass, which was located in exploration line-14 (point 1408 and point 1409). The cumulative settlement is over $3478.4 \mathrm{~mm}$. The subsidence displacements of the hanging wall rock mass were about two or three times larger than the foot wall rock. Almost all displacement vectors of monitoring points were pointing to the direction of the mined-out area. Currently, only a subsidence center was determined on the ground. The rock mass of exploration line-14 moved strongly. The major reason of ground subsidence and overlying rock mass movement is large-scale stress adjustment, and redistribution resulted in the elasticplastic deformation of the surrounding rocks and squeezing of the filling body.

Figure 3(b) shows the vertical displacement of points set in exploration line-14 from 2001 to 2017. Three points were located in the foot wall side and the upper part of rock fracture zones: point 1401 , point 1402 , and point 1403 . The vertical displacement increased slowly in the initial monitoring of the foot wall rock (1401-1403). In the past five 


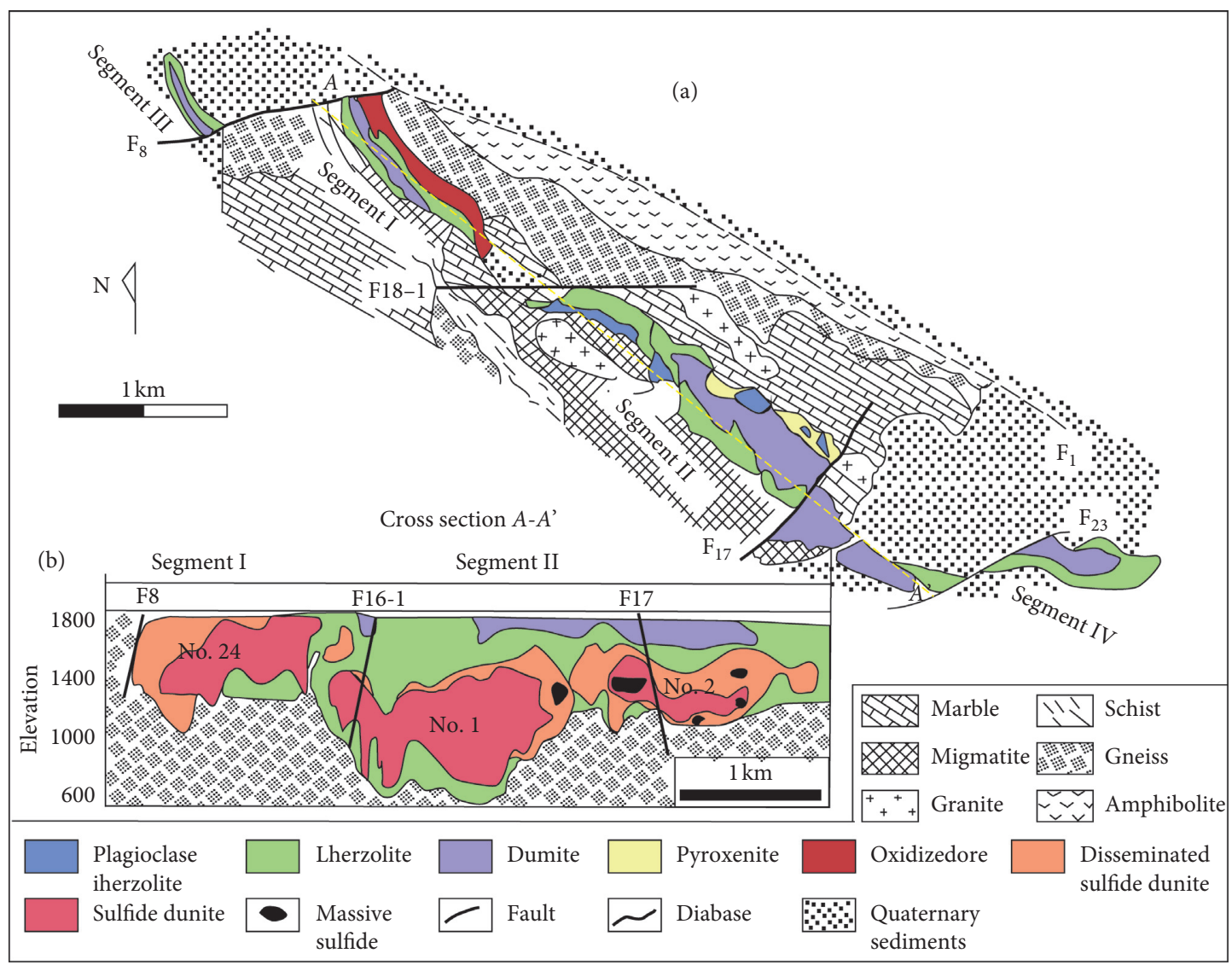

Figure 1: Geological map of the study area: (a) the main tectonic units of the Jinchuan mine; (b) simplified geological map and a cross section of the Jinchuan mine.

years, the cumulative curve of vertical displacements with relatively steep slopes showed that the increase rate of the vertical displacement was larger. For every curve of vertical displacement, the displacement changed slowly in the 1401-1404 area. Figure 3(c) shows horizontal displacements of monitoring points. The rock of 1402-1405 has moved strongly. The deformation of the rock fracture zones resulted in the large horizontal displacement in the foot wall rock.

3.2. Fissure Characters in Exploration Line-14. Besides ground subsidence monitoring, fissures in the mining area were also monitored, periodically. The distribution of fissures is shown in Figure 4(a). Fissure F011-F012 was located in the upper part of rock fracture zones. The deformation of fissures is shown in Figures 4(b)-4(d). From investigation, the integrity of the rock mass in fissure F001-F002 and fissure F091-F092 is found better. So, the deformation of fissure F001-F002 and fissure F091-F092 is considered as the control group for fissure F011-F012 analysis. Fissure F091F092 located was on the hanging wall rock, and fissure F001F002 and fissure F011-F012 were located on the foot wall rock. For every fissure, two points (\#1 and \#2) were set in relative positions in two sides of the fissure, as shown in Figure 4(a).

The curve of the relative tensile deformation of fissures is shown in Figure 4(b). Fissure F011-F012 deformed in the stretching phase. On the contrary, fissure F001-F002 deformed in the closed phase. The tensile deformation indicates fissure stress to some degree. So, the major stress of fissure F011-F012 on the ground surface was tension stress.

The horizontal relative displacement showed rupture deformation along the fissure strike direction under shear stress. The horizontal displacements of fissure F011-F012 and fissure F001-F002 were found to be less than fissure F091-F092. So, the horizontal displacement of the hanging wall rock fissure is found to be larger than the foot wall rock fissure. The ground shear stress of fissure F011-F012 was small. The relative vertical displacement of fissures is shown in Figure 4(d). The relative vertical displacement equals displacement -\#2 subtracted displacement $-\# 1$ in each fissure. The vertical displacement of points located near the ore-body side is found to be larger than the another side. The vertical displacement of fissure F011-F012 was the largest due to the influence of underground rock fracture zones.

\section{Experimental Test of Soft Material}

The simulation test of soft material was used to analyze the mechanism of rock fracture zone deformation influenced by mining engineering. The soft material test was applied in studying different issues, such as landslide deformation, open-pit slope tumbled, and rock mass movement in the mining area [20-24]. The advantage of the soft material 


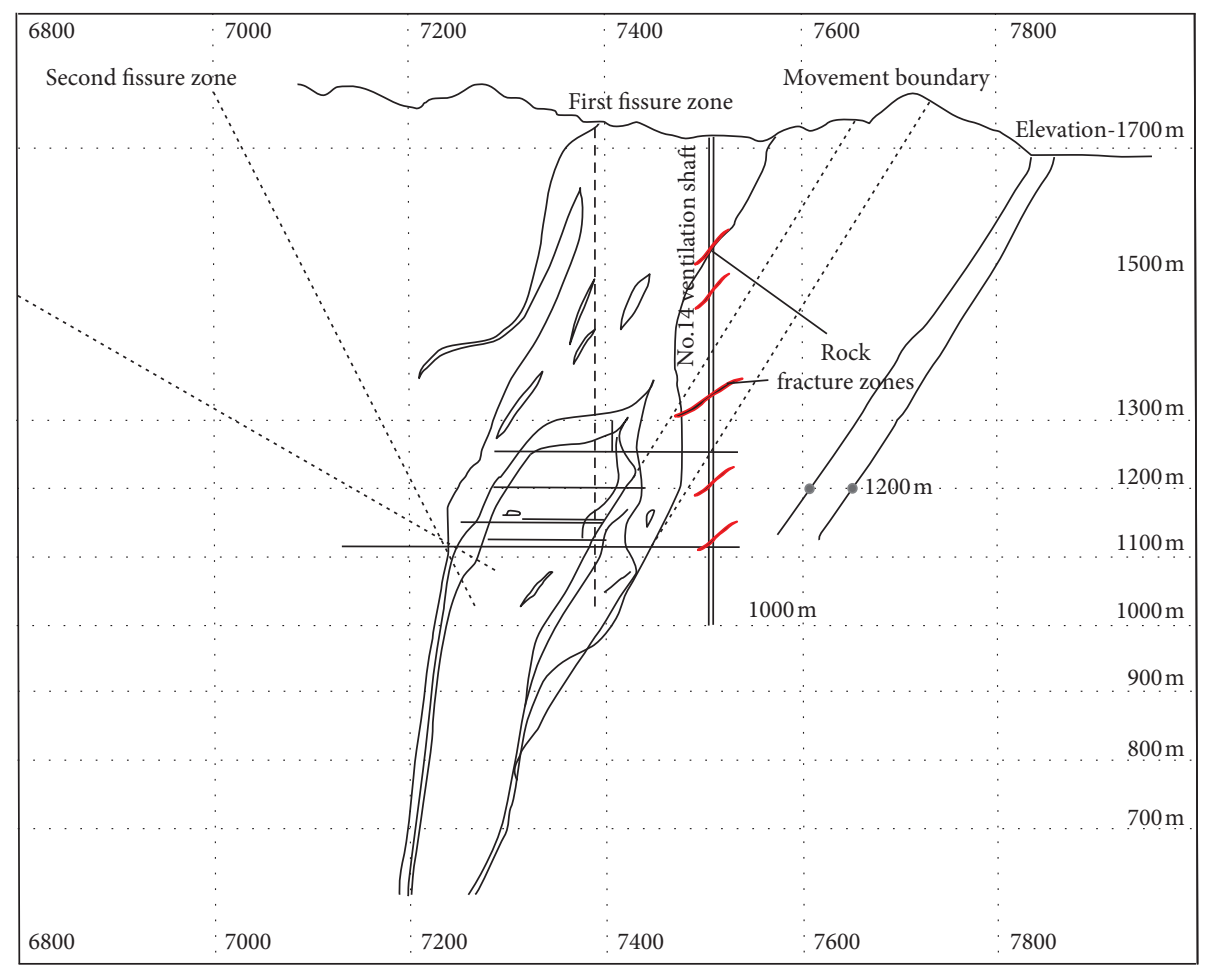

FIGURE 2: Sketch map of the exploration line-14 profile.

experiment is that it is conducted under self-weight stress conditions for rock deformation analysis in the mining area. The model demonstrated the relative positions of fracture zones, mining area, and overlying rock mass. The essential characteristics of the deformation of the fracture zones and the movement of overlying rock mass were analyzed by this soft material test. The empty area of the test model represents the upper-part ore-body mining (corresponding elevation is $1334-1280 \mathrm{~m}$ ), and the mining area has been simplified.

4.1. Experiment Material and Procedure. The experimental model used synthetic, soft, and elastic-plastic material for the test, as shown in Figure 5. The experimental model used the vertical mold by two glass sheets with a fused mixture. The mixture was made of gelatine, glycerine, and water in proportions of $1: 6: 8$ by weight. The elastic modulus of the solidified fused mixture was $0.01 \mathrm{MPa}$, and the Poisson ratio was about 0.4 . The fused mixture was solidified in two days at room temperature, then the framework was laid flat, and finally, glass sheets were removed. The rock fracture zone and monitoring points were set, and the origin positions were labeled on the glass sheet. After this process, the designed excavation was cut. Then, deformation was observed under only self-weight stress conditions by reinstalling the glass sheets and restanding the model.

4.2. Deformation of the Rock Fracture Zone. The deformation of nodes of the physical experiment was handled by software, and the vectors of node displacement are shown in Figure 6(a). The relative displacements of the hanging wall rock and the foot wall rock of the fracture zone (labeled by white box) are shown in Figures 6(b) and 6(c).

The deformation of the rock fracture zone in the model was mainly vertical compression. The value of the vertical displacement was found to be larger than the horizontal displacement. By comparing two sides of fracture zone deformation, horizontal displacements of the hanging wall rock were found to be smaller than the foot wall rock. However, vertical displacements of the hanging wall rock were found to be larger than the foot wall rock.

Four layers of the rock stratum displacement are analyzed in Figure 7 . Layer- 8 rock stratum located below the mining section occurred during floor heaving in the central part of the rock stratum. The vertical displacement decreased from layer- 1 to layer- 8 . The vertical displacement of nodes located between the mining area and the fracture zone (labeled by the red line in Figure 7) resulted in a slight mutation caused by mining and the compression of the fracture zone. The compression of the fracture zone and mining work resulted in the ground tensile fissure, as shown in Figure 5. These physical models analyzed the mechanism and characteristics of deformation and movement of the fracture zone. Combined with the ground monitoring data, the characteristics and mechanism could provide some explanations for the situation in the field to some degree.

\section{Numerical Simulation Analysis}

5.1. Numerical Simulation Model Parameters. The simulation model was developed by the finite element method for analyzing the deformation of small-scale rock fracture zones located in the foot wall rock mass. According to the situation 


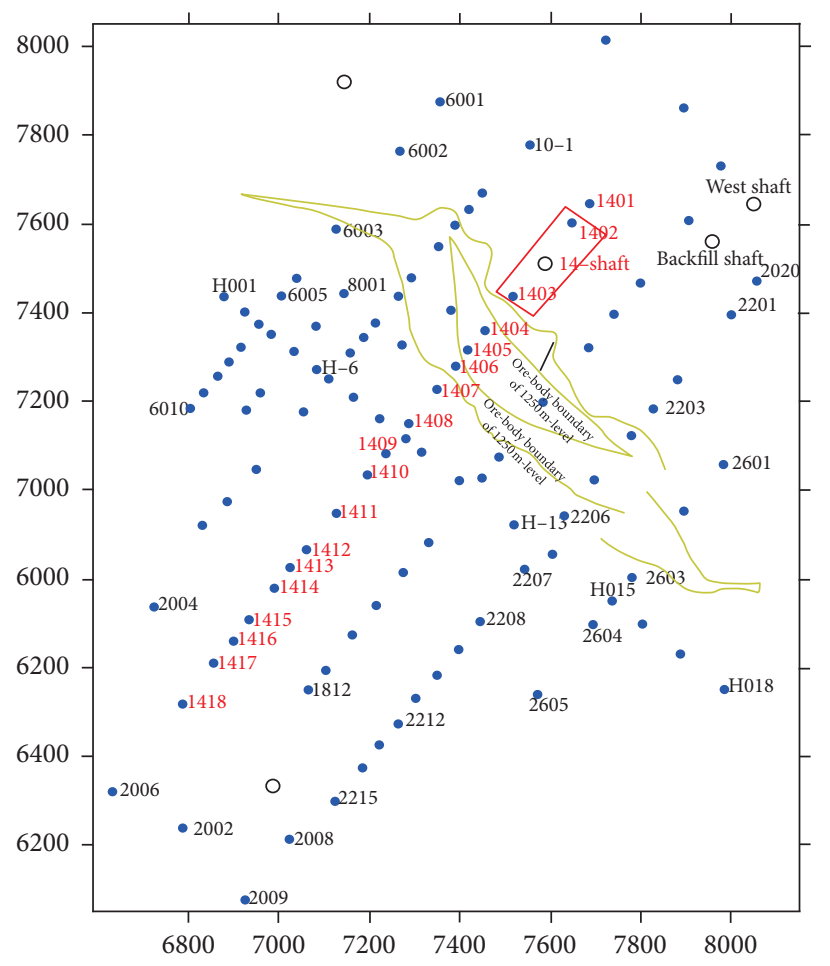

(a)

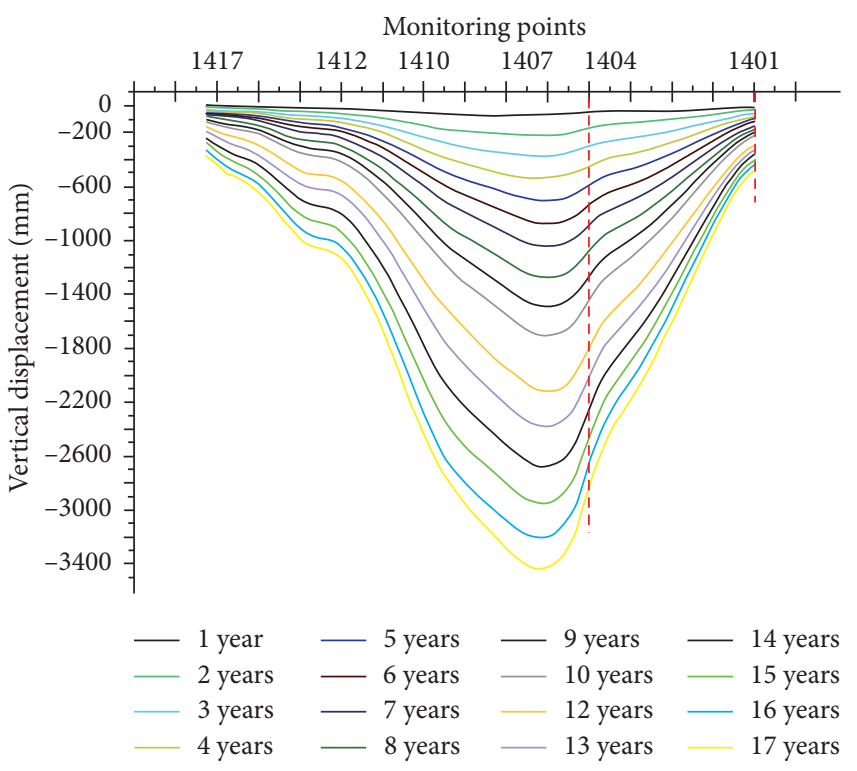

(b)

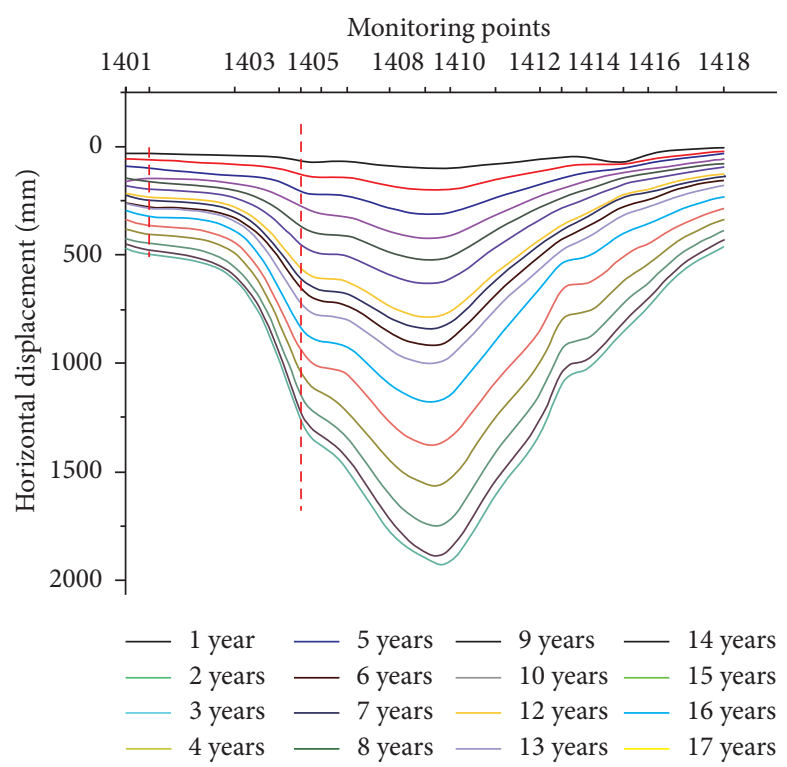

(c)

FIGURE 3: Distribution of monitoring points and the displacement of points set in exploration line-14: (a) monitoring point distribution; (b) vertical displacement of points set in exploration line-14; (c) horizontal displacement of points set in exploration line-14.

of the mining area, the development of the simulation model is shown in Figure 8.

The levels of the top layer and the first layer of the ore body were $-100 \mathrm{~m}$ and $-366 \mathrm{~m}$. The surface elevation is approximately $1730 \mathrm{~m}$, and the elevation of the first mining layer is $1334 \mathrm{~m}$. The thickness of the mining level was set $50 \mathrm{~m}$ by practical mining engineering. In the simulation model, the total thickness of the ore body was $350 \mathrm{~m}$; finally, the thickness of backfill was $250 \mathrm{~m}$. The distance of the ore- body boundary to rock fracture zones was $100 \mathrm{~m}$. In our investigation, five representative rock fracture zones were selected. These rock fracture zones were distributed from $-180 \mathrm{~m}$ depth to $-700 \mathrm{~m}$ depth. The numerical simulation model represents the area of the Jinchuan mine from $-100 \mathrm{~m}$ to $-750 \mathrm{~m}$ of the underground, and the corresponding elevation is $1600 \mathrm{~m}$ to $950 \mathrm{~m}$, as shown in Figure 2. Numerical model parameters were set according to the test result of laboratory rock mechanics, as shown in Table 1. 


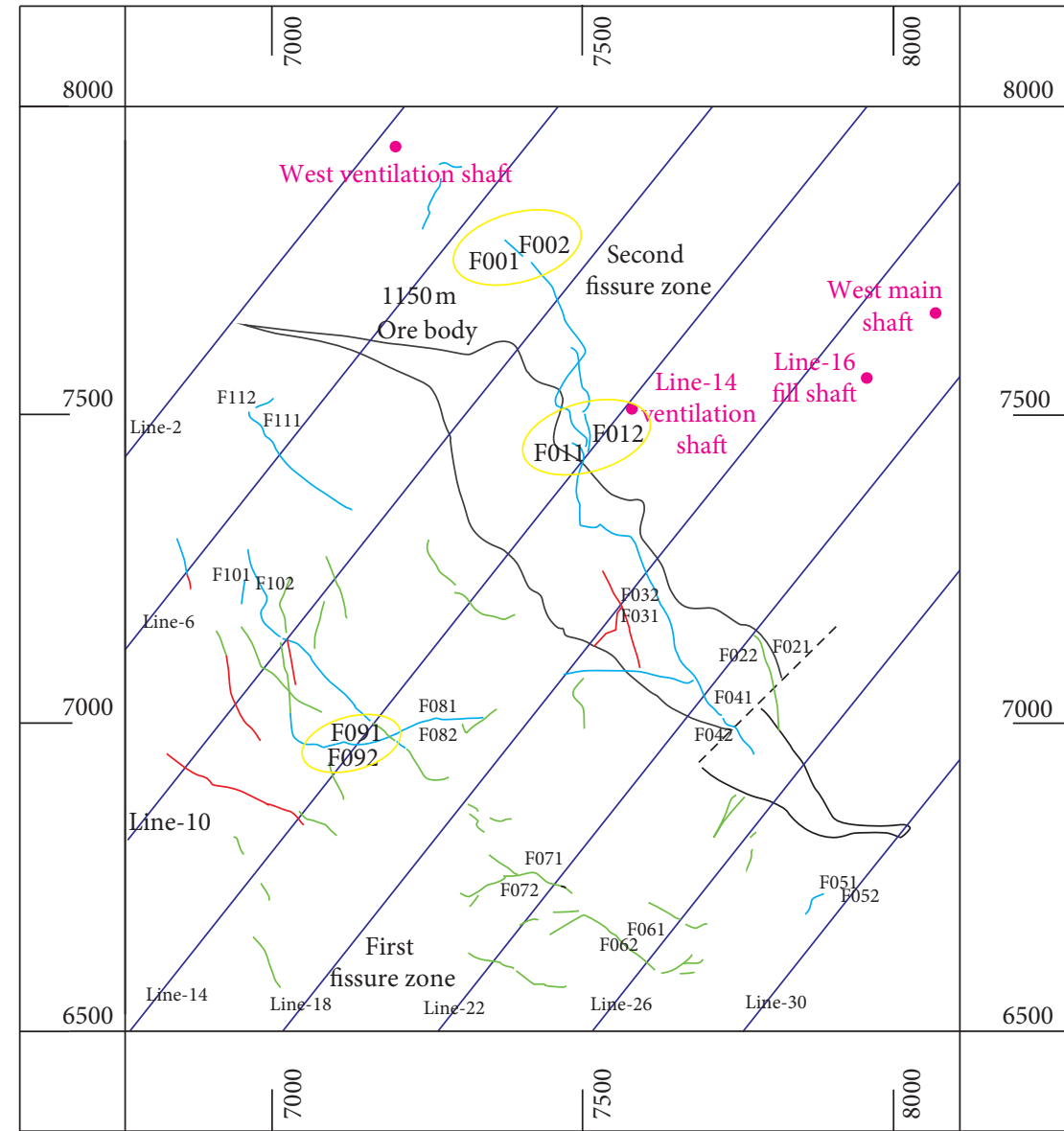

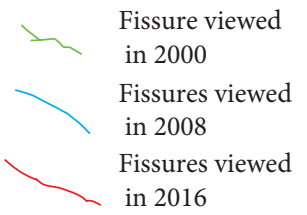

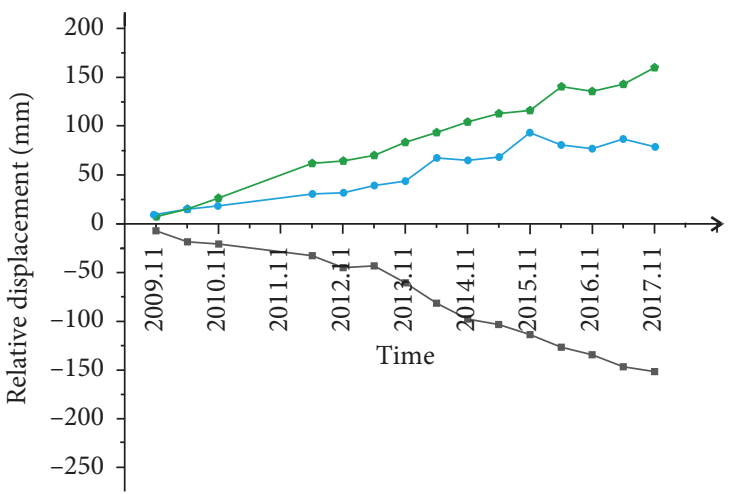

$\rightarrow$ F091-F092 tensile relative displacement

- F011-F012 tensile relative displacement

$\Longrightarrow$ F001-F002 tensile relative displacement

(b)
Fissures

analysis

F001 Monitoring

point

(a)

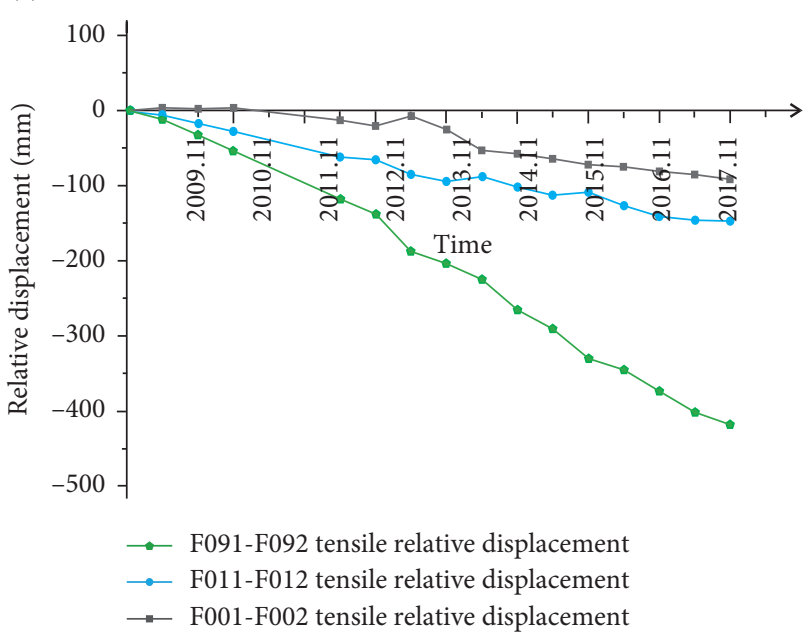

(c)

Figure 4: Continued. 


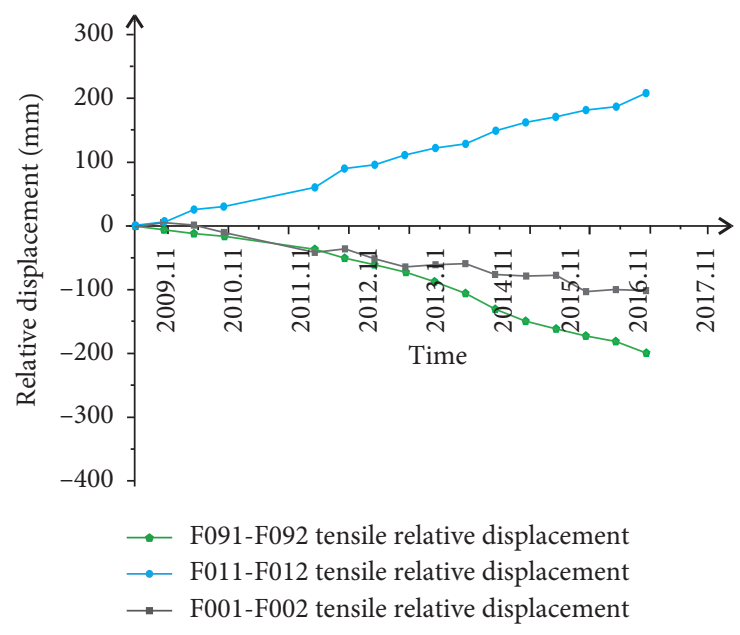

(d)

Figure 4: Monitoring and displacement of fissures: (a) fissure monitoring distribution; (b) tensile relative displacement; (c) horizontal relative displacement; (d) vertical relative displacement.

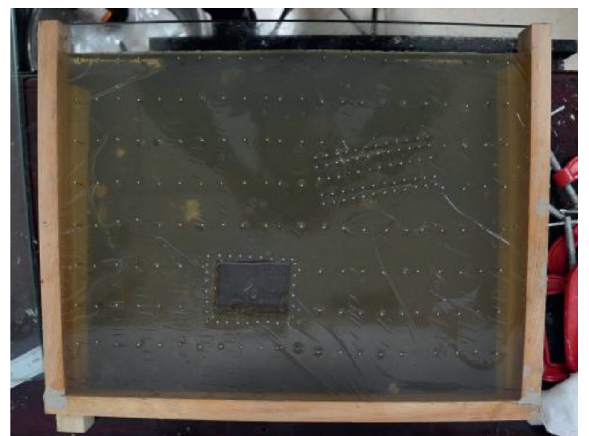

(a)

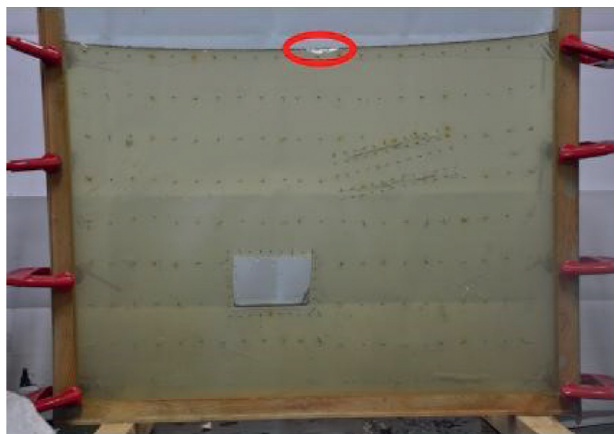

(b)

Figure 5: Soft material experimental model.

The ore body was downward mined by panels with a width of $50 \mathrm{~m}$. Once excavation was completed within an access drift, the void was filled using backfill before the next access drift was excavated. After the last void was filled in one layer, mining work proceeded to the next layer. The horizontal stress coefficient was set as 1.5-2.

5.2. Validation of the Numerical Model. Three relative nodes, node 2952, node 5258, and node 5218, were distributed on the upper part of rock fracture zones in the numerical model. The corresponding ground monitoring points in the mining area are point 1402 , point 1403 , and point 14 -well (point 1403 is located near the ore body, and point 14-well is located between point 1403 and point 1402; these three points have been labeled in Figure 3(a) by a red frame). Figure 9 shows vertical displacement rates and cumulative displacements in ground monitoring points. The vertical displacement of point 1403 was the largest, and the vertical displacement of point 1402 was the smallest.

Therefore, the vertical displacements of monitoring points decreased with an increase in the distance between the point position and the ore body. In the numerical model, node 2952 was located near the ore body, and node 5318 was located between node 2952 and node 5258. The vertical displacement of numerical model points is shown in Figure 10. The maximum vertical displacement rate was $-98 \mathrm{~mm}$ in field monitoring. The maximum value was $-55 \mathrm{~mm}$ in the numerical model. The maximum value of the cumulative vertical displacement was $-1650 \mathrm{~mm}$ in field monitoring. The maximum cumulative displacement was $-1180 \mathrm{~mm}$ in the numerical model. The variation trend of displacements was consistent with field monitoring displacements. The numerical model was verified to some degree.

\subsection{Stress and Deformation of the Rock Fracture Zones in the} Numerical Model. In the numerical model, vertical displacements of four fracture zones (fracture zone-1 to fracture zone-4) are shown in Figure 11.

The maximum values of the vertical displacement of the hanging wall rock in four fracture zones were $1202.43 \mathrm{~mm}$, $1099.18 \mathrm{~mm}, 1014.73 \mathrm{~mm}$, and $630.959 \mathrm{~mm}$, respectively. 


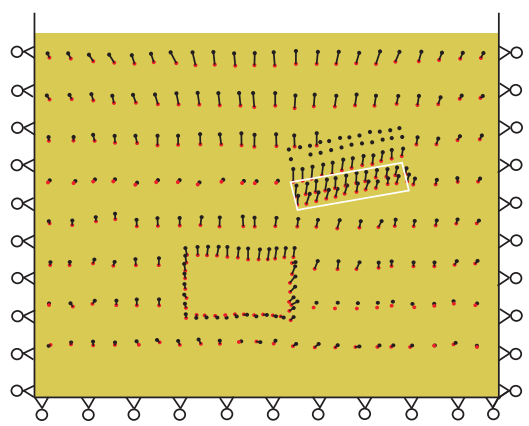

(a)

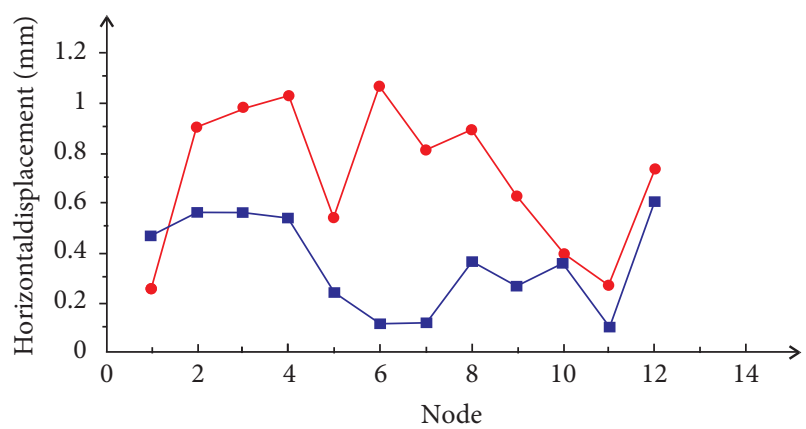

Horizontal displacement of hanging wall rock

$\rightarrow$ Horizontal displacement of foot wall rock

(b)

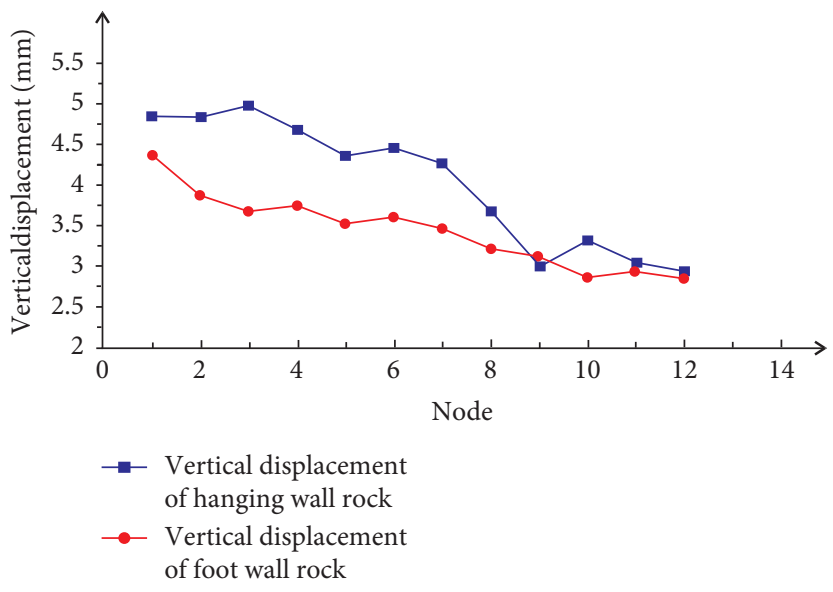

(c)

Figure 6: Physical experiment results using soft material: (a) deformation vectors of physical model nodes; (b) horizontal relative displacement; (c) vertical relative displacement.

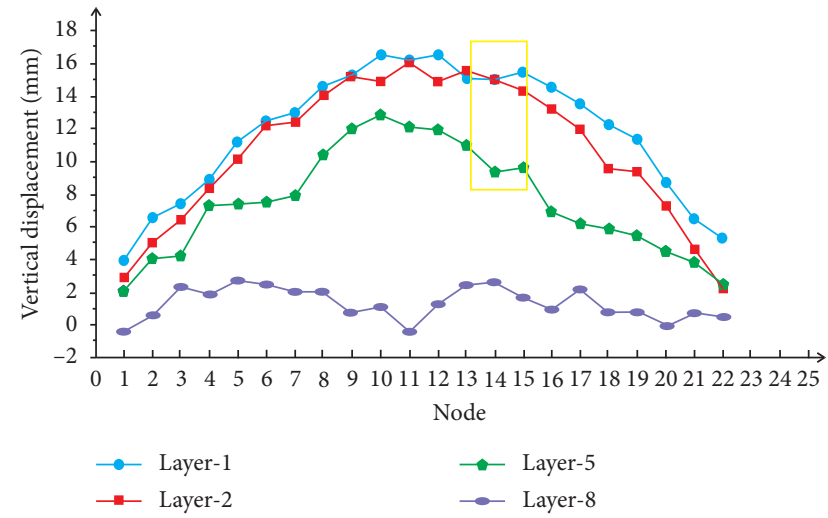

Figure 7: Vertical displacements of the rock stratum.

The maximum values of the vertical displacement of the foot wall rock were $1114.49 \mathrm{~mm}, 1021.84 \mathrm{~mm}, 815.098 \mathrm{~mm}$, and $372.355 \mathrm{~mm}$, respectively. Model validation showed that the numerical model results were slightly smaller than field monitoring. However, the results of rock fracture zones in the numerical model could represent the fracture

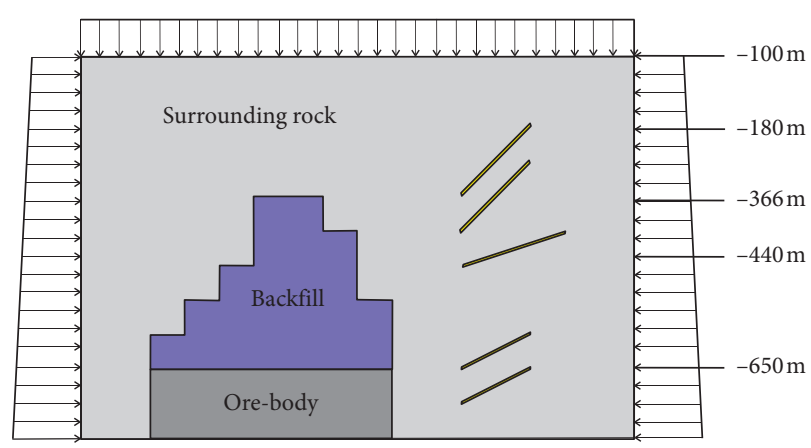

FIGURE 8: The sketch map of the simulation model.

deformation in the field mining area. The shallow fracture zone deformation of the hanging wall rock was about two times that of the deep fracture zone. However, the shallow fracture zone deformation of the foot wall rock was about three times that of the deep fracture zone.

For these rock fracture zones, the horizontal displacements were far smaller than vertical displacements, as 
TABLE 1: Material parameters of the numerical model.

\begin{tabular}{lccccc}
\hline Material & Elastic modulus $(\mathrm{GPa})$ & Poisson's ratio & Density $\left(\mathrm{kg} / \mathrm{m}^{3}\right)$ & Friction angle $\left(^{\circ}\right)$ & Cohesion $(\mathrm{MPa})$ \\
\hline Surrounding rock & 61 & 0.26 & 3200 & 56 & 14.5 \\
Ore body & 77 & 0.26 & 3000 & 56.5 & 18.2 \\
Backfill & 3.02 & 0.15 & 2700 & 49.3 & 35 \\
Fracture zones & $0.06-0.08$ & 0.13 & 2000 & -87 \\
\hline
\end{tabular}

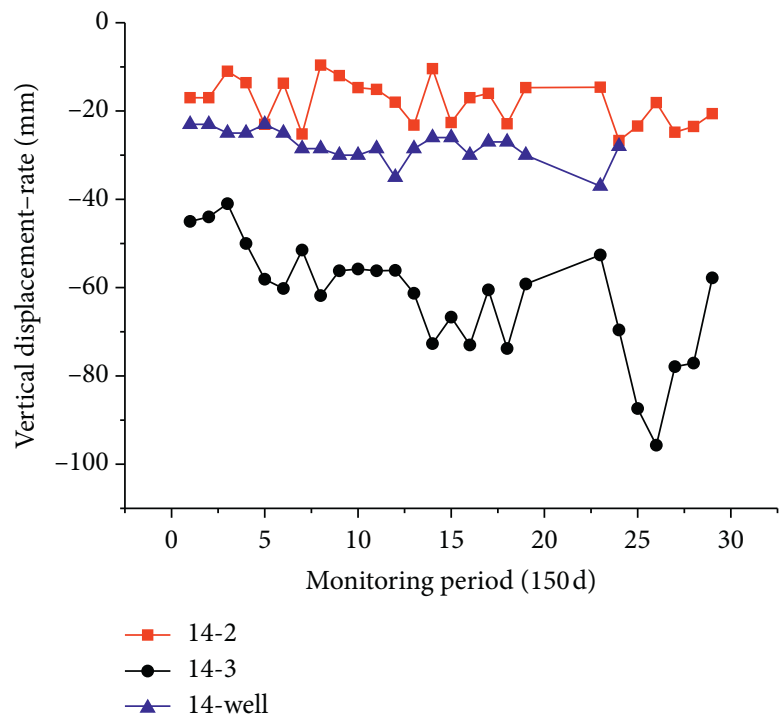

(a)

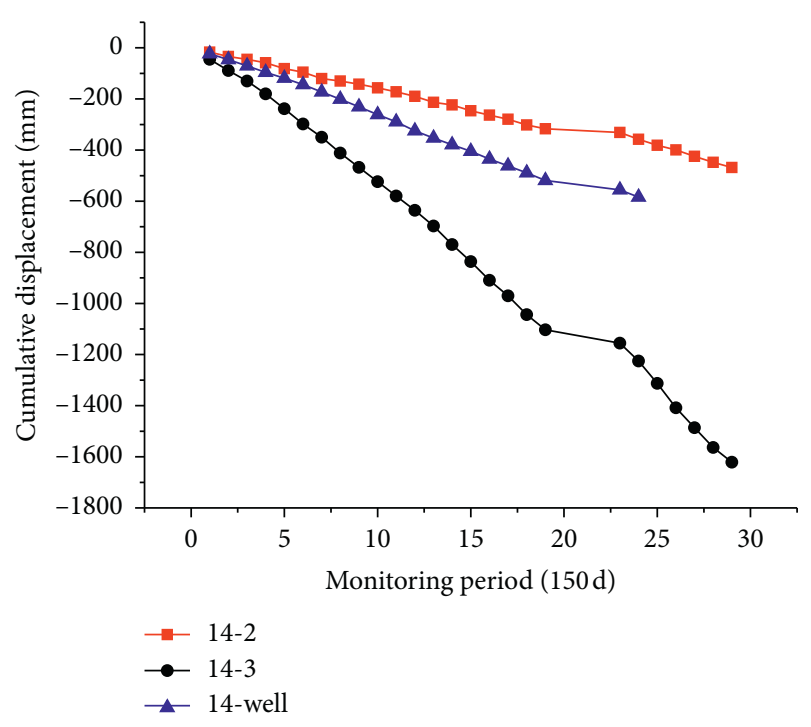

(b)

FIGURE 9: Displacements of field monitoring: (a) displacement rate; (b) cumulative displacement.

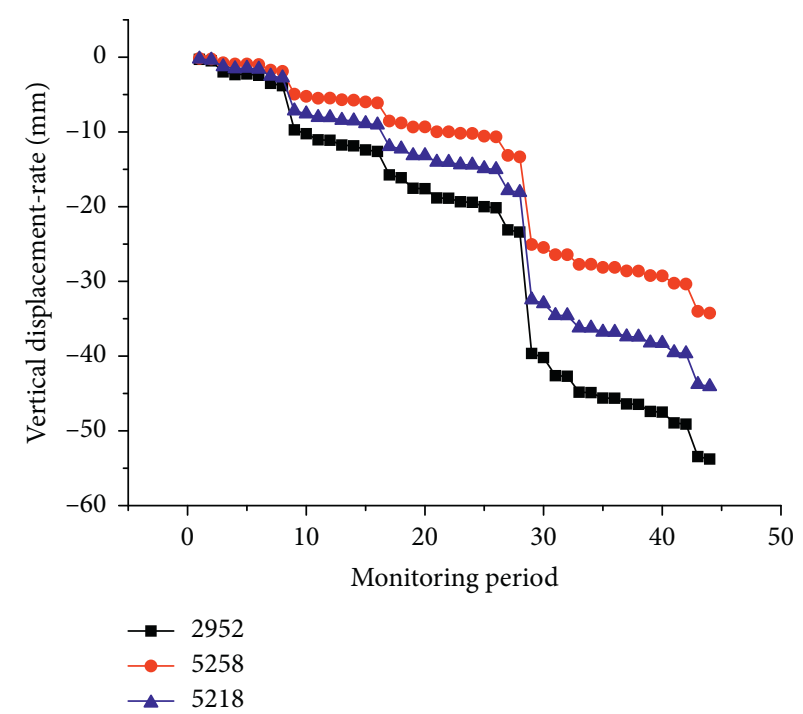

(a)

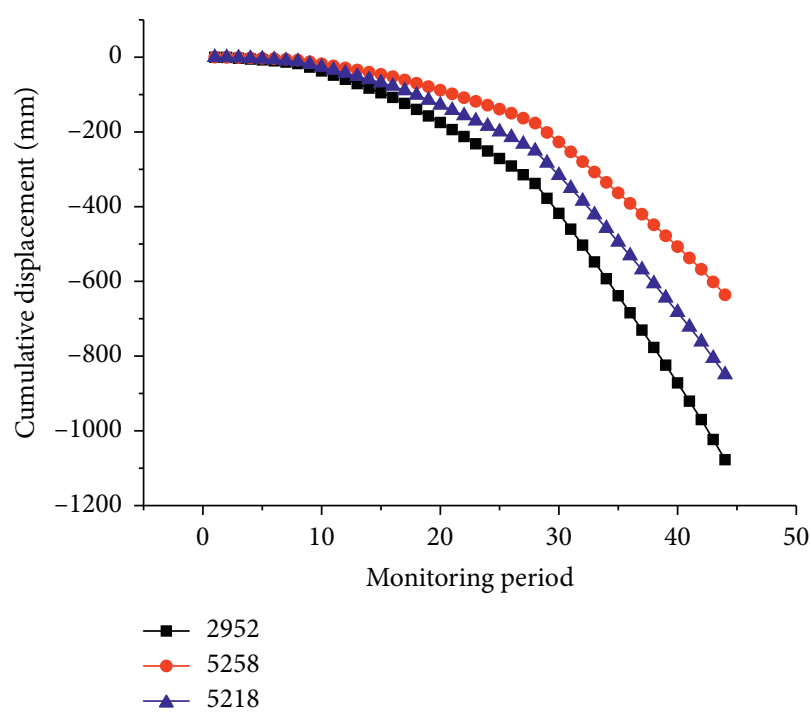

(b)

Figure 10: Displacements of the numerical model: (a) displacement rate; (b) cumulative displacement.

shown in Figure 12. Features of these fracture zones in horizontal deformation are different. The horizontal displacement of the hanging and the foot wall rock in fracture zone-1 was the same as the physical model fracture zone deformation. However, for deeper fracture zones, horizontal displacements were moved in different directions. 


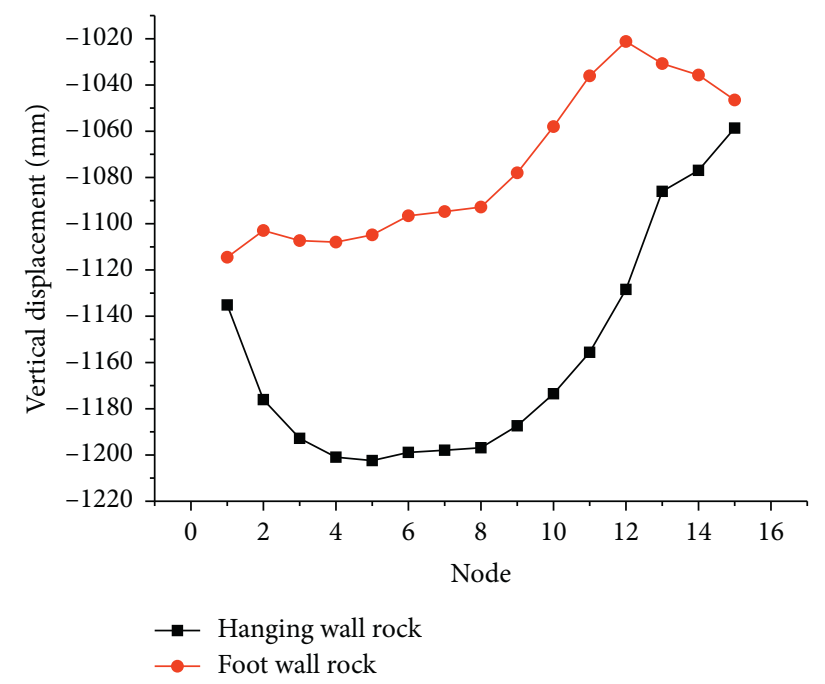

(a)

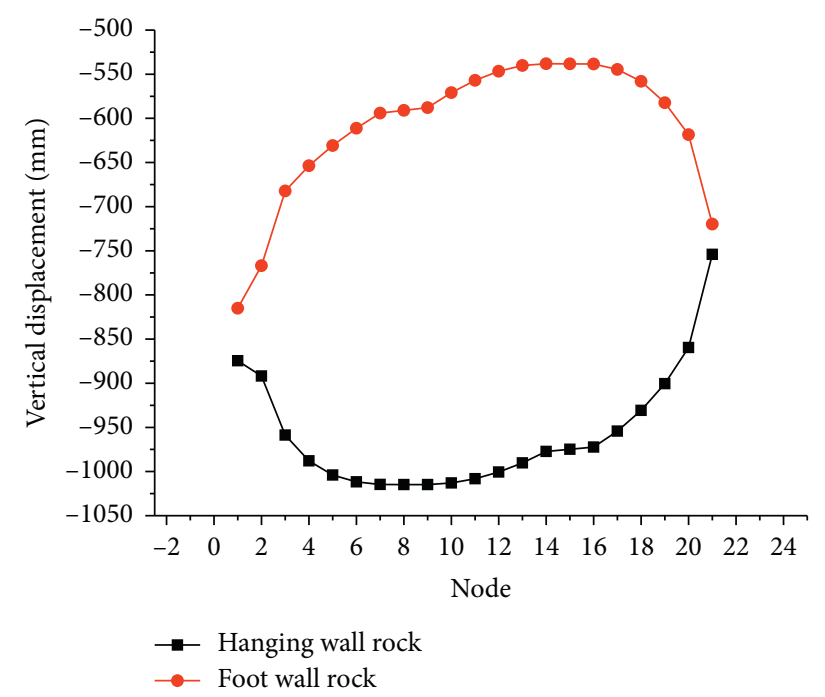

(c)

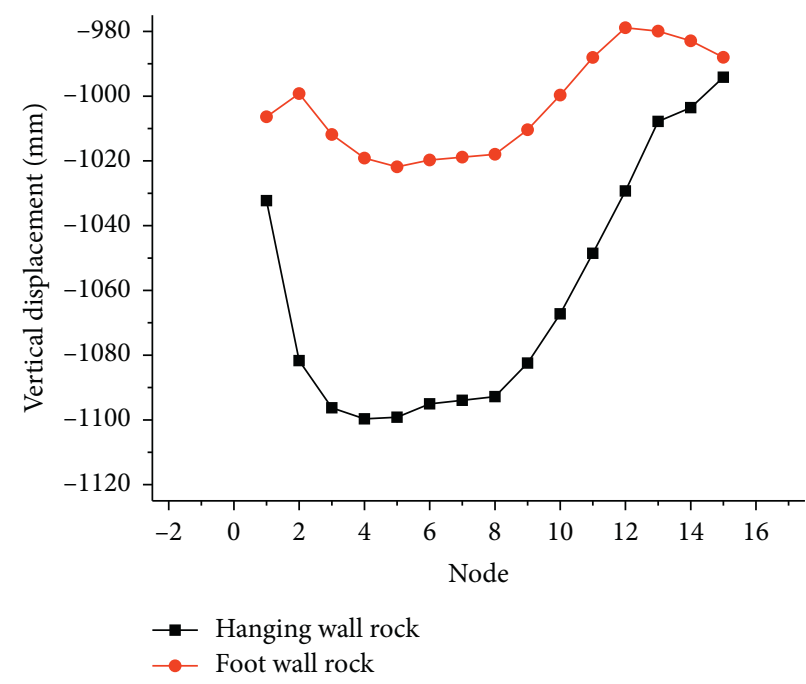

(b)

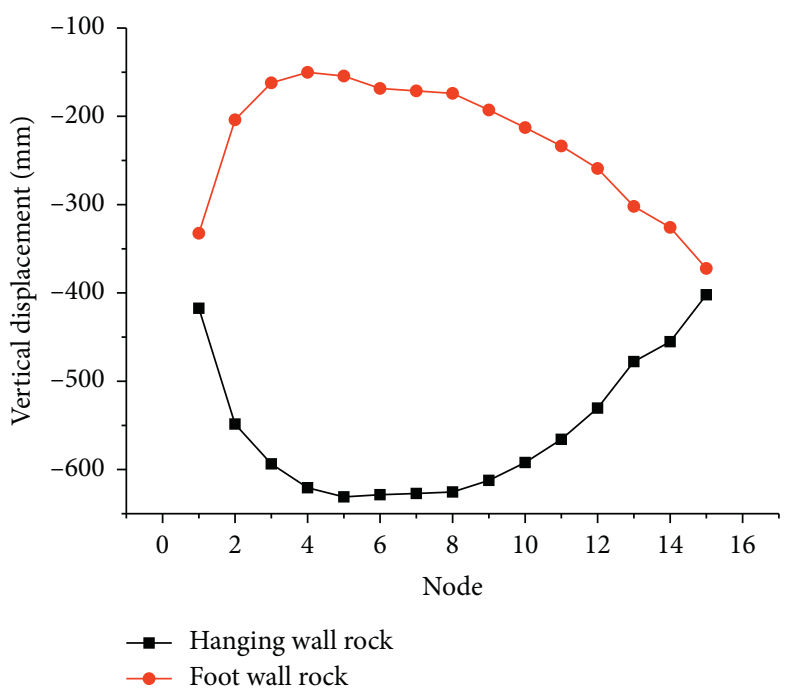

(d)

Figure 11: Vertical displacement of two sides of rock fracture zones in deep mining: (a) vertical displacement of fracture zone-1; (b) vertical displacement of fracture zone-2; (c) vertical displacement of fracture zone-3; (d) vertical displacement of fracture zone-4.

Basically, the foot wall rock was moved to the mining section, and the hanging wall rock was moved away from the mining section.

The difference of the effective stress for each node represents unbalance stress that influences the node movement. The shallow fracture zone deformation was larger than others, so the stress of rock fracture zone-1 located underground the shallow rock layer was analyzed in this part. Mining work, operated from the shallow layer to the deep layer in the underground, was divided into three phases according to the mining depth: mining in the shallow part, mining in the middle part, and mining in the deep part. Different mining phases resulted in different stress conditions for fracture zone-1. In Figure 13, blue labels represent the effective stress difference of the hanging wall rock, and red labels represent the effective stress difference of the foot wall rock. The effective stress differences of the foot wall rock were found to be larger than the hanging wall rock in phases of mining in shallow and middle parts. However, unbalance stress distribution represented by the effective stress difference was totally changed in the deep mining phase, both the hanging and the foot wall rock. In the right part of fracture zone- 1 stress curves, the unbalance stress changed sharply. This unbalance stress was the major reason for the movement of the fracture zone-1 rock.

\subsection{Fracture Zone Deformation Analysis of the Hanging Wall} Rock and the Foot Wall Rock. In the study area, underground rock fracture zone deformation has resulted in some structural damage. The mining depth increase induced to the movement and deformation of the surrounding rock. Figures 14 and 15 show the plastic deformation area distribution and the plastic strain vector distribution of rock 


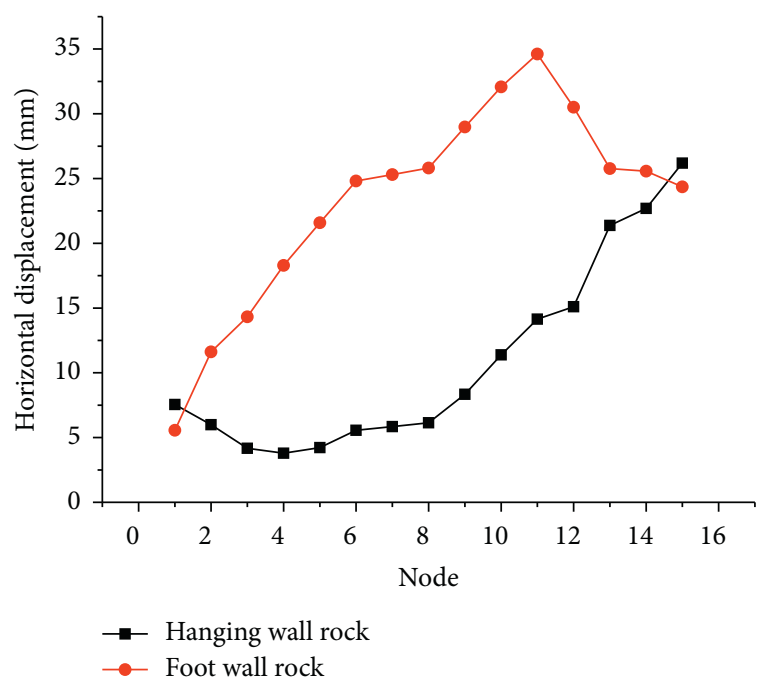

(a)

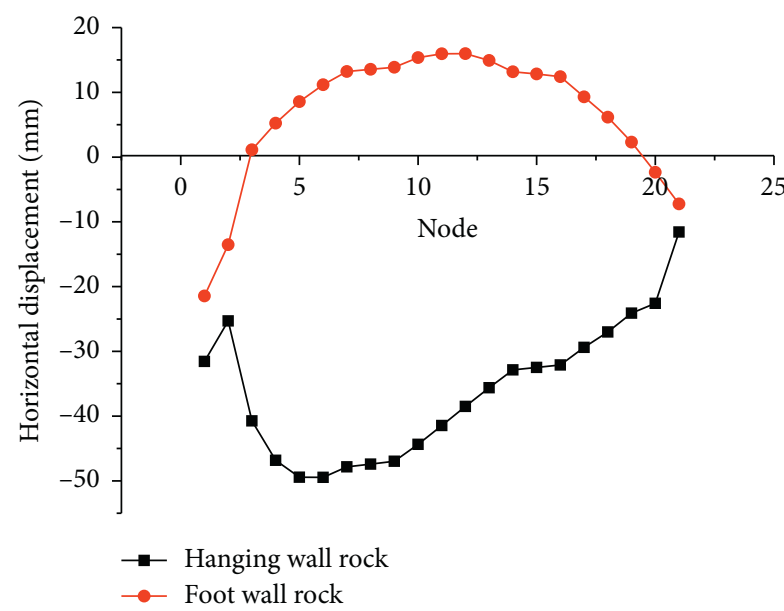

(c)

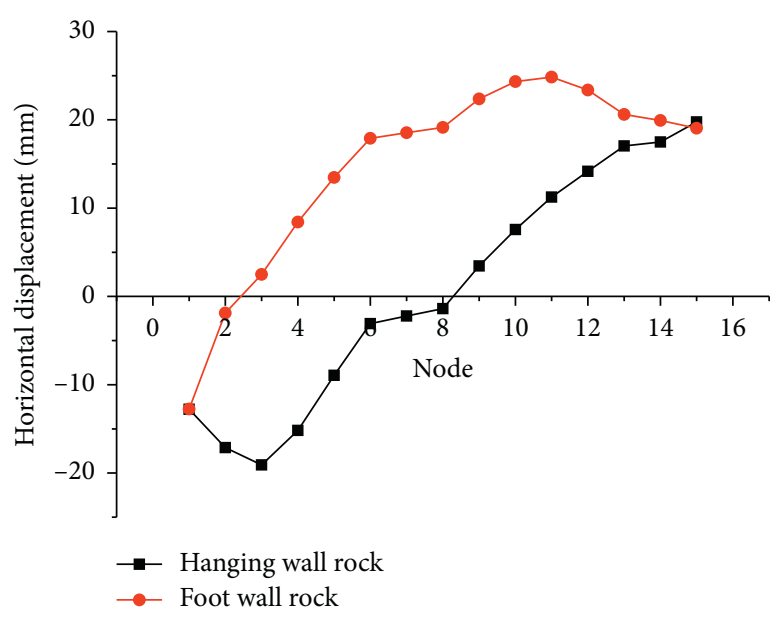

(b)

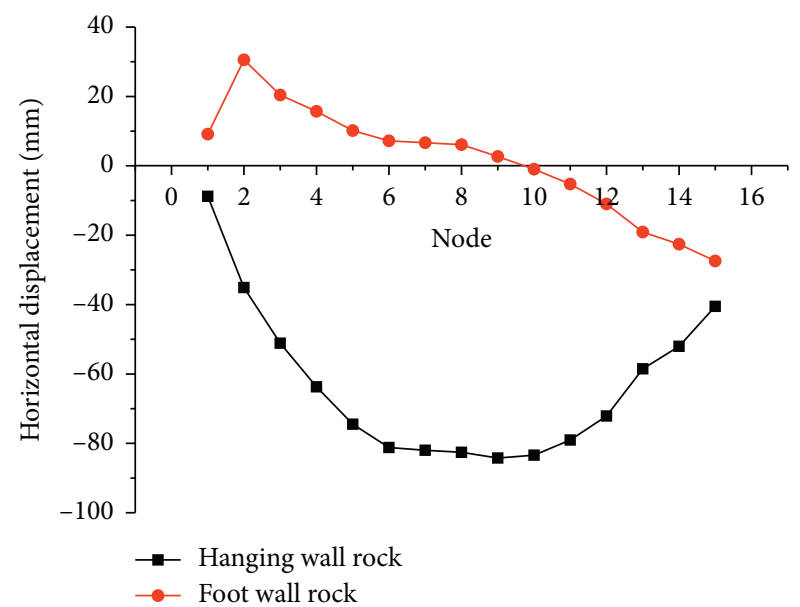

(d)

FiguRe 12: Horizontal displacement of two sides of rock fracture zones in deep mining: (a) horizontal displacement of fracture zone-1; (b) horizontal displacement of fracture zone-2; (c) horizontal displacement of fracture zone-3; (d) horizontal displacement of fracture zone-4.

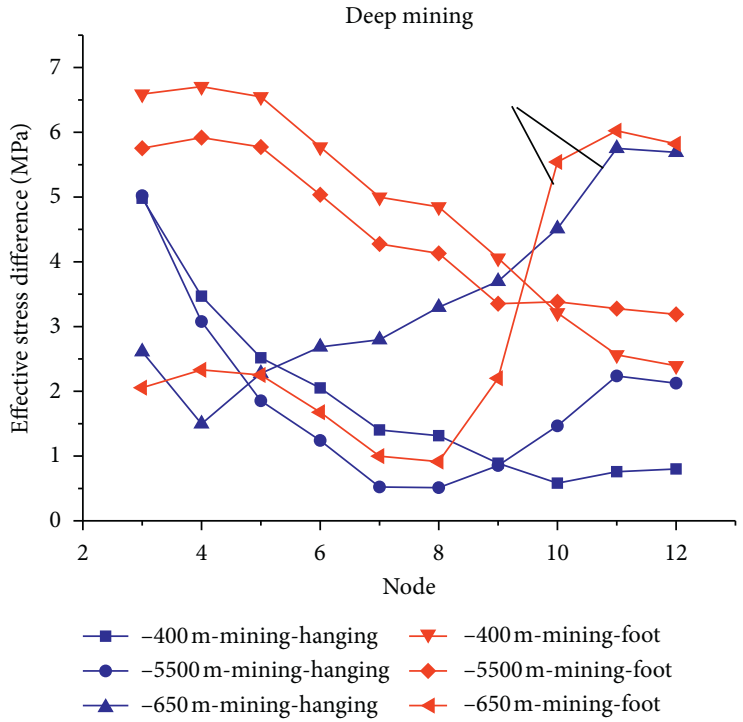

FIgURE 13: Curve of the effective stress difference in fracture zone-1 at different mining depths. 

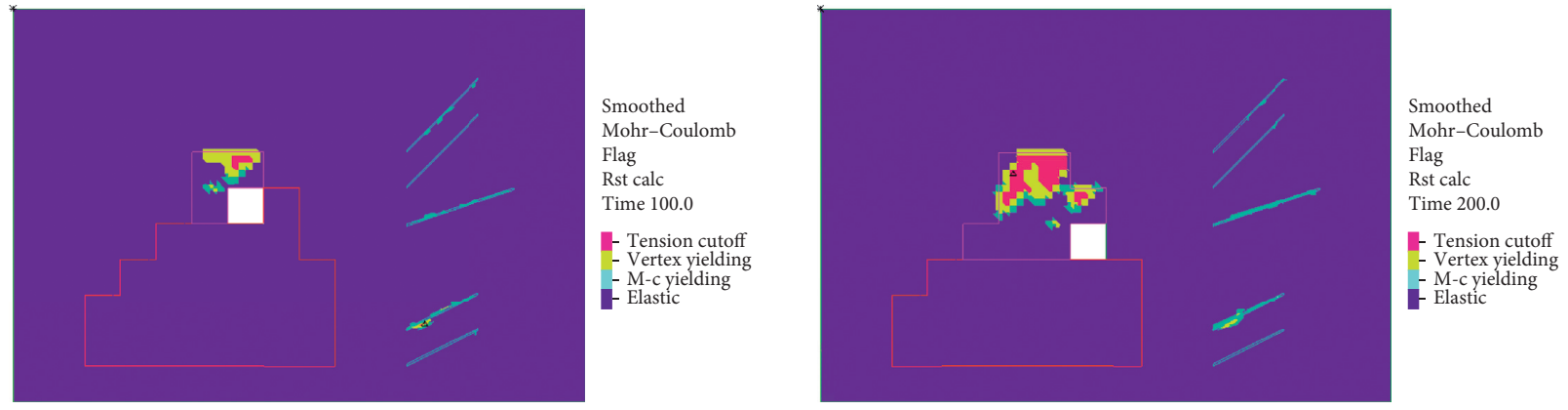

Maximum
$\Delta$ Tension cutoff node 4093

Minimum
* Elastic node 1393

Maximum

Minimum

$\Delta$ Tension cutoff node 1047

* Elastic node 1393

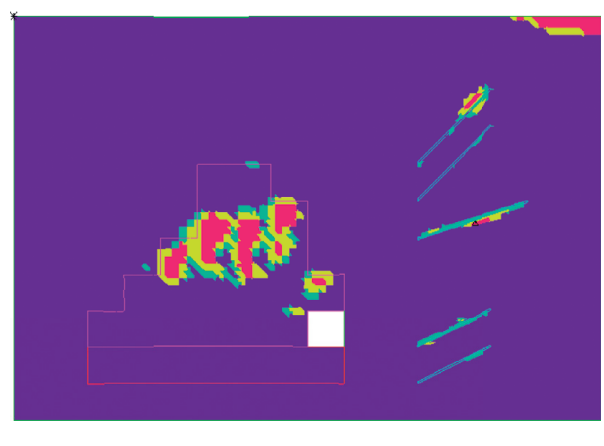

Smoothed

Mohr-Coulomb

Flag

Rst calc

Time 460.0

- Tension cutoff

- Vertex yielding

- Elastic

Figure 14: Plastic deformation distribution in the numerical model.

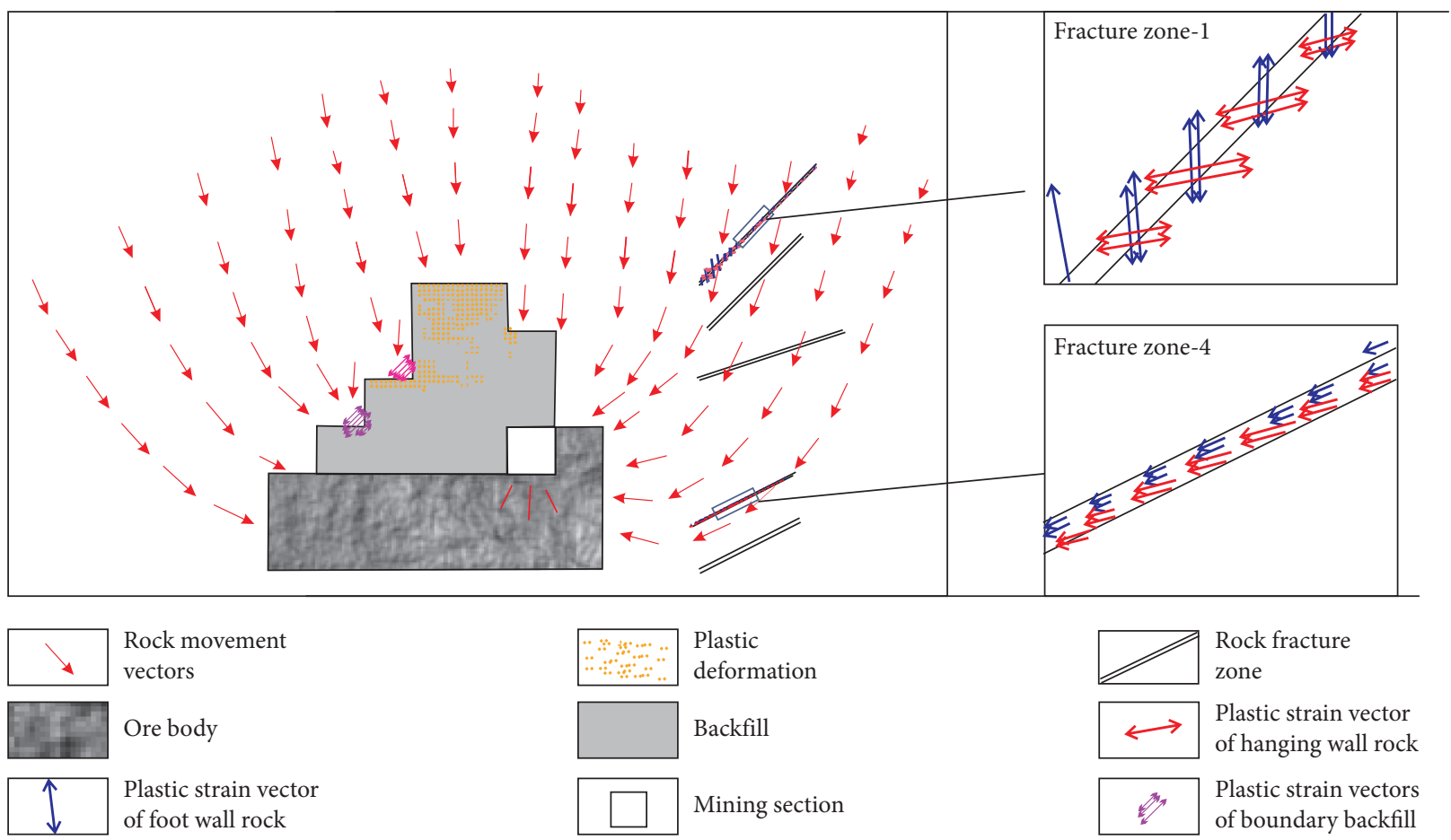

FIgURE 15: Plastic strain vectors of fracture zones and rock movement in the numerical model.

fracture zones in the deep mining phase. Typical fracture zones, fracture zone- 1 and fracture zone- 4 , representing the shallow fracture and the deep fracture, respectively, were analyzed in this part. The plastic strain vectors of fracture zone-1 were larger than fracture zone- 4 . So, the plastic deformation of the shallow fracture was larger than the deep one because the heavy vertical pressure of the deep fracture helps in stability. The vector direction indicates the trend of 
rock movement. The plastic strain of fracture zone- 4 vectors was found to be horizontal to both sides of the fracture. The rock of both sides of fracture zone-4 moved slightly and synchronously. However, characteristics of plastic strain vectors of fracture zone- 1 were completely different.

The plastic strain of the hanging wall rock of fracture zone- 1 vectors was found to be different from the foot wall rock. The vertical plastic strain vectors of the hanging wall rock of fracture zone- 1 were dominated, whereas the plastic strain vectors of the foot wall rock were horizontal, caused by the horizontal tectonic stress. Fracture zone-1 deformed by the squeezing of the hanging wall rock.

As mentioned above, the ventilated shaft passed through these rock fracture zones. This shaft was damaged during the process of mining. The damaged area of the shaft concentrated on the scope of -165 to $-220 \mathrm{~m}$ depth, and the deeper part of the shaft was found to be stable. Fracture zone-1 was matching to the location of the damaged zone. The damaged zone of the shaft was filled with a lot of waste rocks, which demonstrates that the rock mass of this zone was compressed.

Field monitoring and numerical simulation showed that mining engineering induced shallow fracture deformation, whereas the deep fracture was found to be relatively stable. The shaft was also damaged on the shallow part and would not cause multipart horizontal dislocation. The lower vertical stress and the heavy horizontal stress resulted in the large unbalance effective stress in the shallow part of the fracture zone. In addition, the overlying rock mass movement and the ground movement promoted the shallow fracture deformation. The vertical displacement of the shallow fracture zone increased the ground fissure tensile deformation.

\section{Conclusion}

The deformation of underground rock fracture zones was analyzed by filed monitoring, physical experiment, and numerical simulation. The fracture deformation was broken structures in the mining area.

Field monitoring indicated features of the ground movement and the surface fissure deformation of the upper part of fracture zones. The vertical displacement increased slowly during the initial monitoring of the foot wall rock. The rock fracture zone deformation resulted in the large horizontal displacement in the foot wall rock. The major stress of the fissure located in the upper part of underground fracture zones was the tension stress. The vertical displacement of the fissure located in the upper part of underground fracture zones was large because of underground rock fracture zone deformation.

In the physical experiment, we studied the mechanism of underground fracture zone deformation induced by mining under self-weight conditions. The vertical displacement was found to be larger than the horizontal displacement in the whole model. The horizontal displacement of the foot wall rock of the shallow rock fracture zone was found to be larger than the hanging wall rock. The vertical displacement of the fracture promoted ground fissure deformation.

Numerical simulation showed that the large unbalance effective stress in the shallow part of the fracture zone was compressed. Mining work showed that the shallow fracture deformed more severely than the deep fracture. The vertical displacement of the shallow fracture zone increased ground fissure tensile deformation.

\section{Data Availability}

The data used to support the findings of this study are included within the article.

\section{Conflicts of Interest}

The authors declare that there are no conflicts of interest regarding the publication of this paper.

\section{Acknowledgments}

The authors would like to express their sincere gratitude to the Jinchuan mine for their data support. This research was funded by the National Natural Science Foundation of China (Grant nos. 41831293, 41772341, and 41877274).

\section{References}

[1] F. G. Bell, T. R. Stacey, and D. D. Genske, "Mining subsidence and its effect on the environment: some differing examples," Environmental Geology, vol. 40, no. 1-2, pp. 135-152, 2000.

[2] G. Swift and D. Reddish, "Stability problems associated with an abandoned ironstone mine," Bulletin of Engineering Geology and the Environment, vol. 61, no. 3, pp. 227-239, 2002.

[3] M. Alber, R. Fritschen, M. Bischoff, and T. Meier, "Rock mechanical investigations of seismic events in a deep longwall coal mine," International Journal of Rock Mechanics and Mining Sciences, vol. 46, no. 2, pp. 408-420, 2009.

[4] M. Fengshan, Z. Haijun, Z. Yamin et al., "GPS monitoring and analysis of ground movement and deformation induced by transition from open-pit to underground mining," Journal of Rock Mechanics and Geotechnical Engineering, vol. 4, no. 1, pp. 82-87, 2012.

[5] H. Xin, M. Fengshan, Z. Haijun, and X. Jiamo, "Monitoring and statistical analysis of mine subsidence at three metal mines in China," Bulletin of Engineering Geology and the Environment, vol. 78, pp. 3983-4001, 2019.

[6] L. Rong, M. Fengshan, G. Jie, and Z. Haijun, "Monitoring and analysis of ground subsidence and backfill stress distribution in Jinchuan Mine, China," Current Science, vol. 115, no. 10, pp. 1970-1977, 2018.

[7] Z. Haijun, M. Fengshan, Z. Yamin, and G. Jie, "Monitoring and analysis of the mining-induced ground movement in the longshou mine, China," Rock Mechanics and Rock Engineering, vol. 46, pp. 207-211, 2013.

[8] D. Kuo, M. Fengshan, G. Jie, Z. Haijun, L. Rong, and L. Feng, "Investigation of the mechanism of roof caving in the jinchuan nickel mine, China," Rock Mechanics and Rock Engineering, vol. 51, pp. 1215-1226, 2018.

[9] A. Vyazmensky, D. Stead, D. Elmo, and A. Moss, "Numerical analysis of block caving-induced instability in large open pit slopes: a finite element/discrete element approach," Rock 
Mechanics and Rock Engineering, vol. 43, no. 1, pp. 21-39, 2010.

[10] E. Bakhtavar, K. Shahriar, and K. Oraee, "Transition from open-pit to underground as a new optimization challenge in mining engineering," Journal of Mining Science, vol. 45, no. 5, pp. 485-494, 2009.

[11] N. D. Rose and O. Hungr, "Forecasting potential rock slope failure in open pit mines using the inverse-velocity method," International Journal of Rock Mechanics and Mining Sciences, vol. 44, no. 2, pp. 308-320, 2007.

[12] D. P. Adhikary and A. V. Dyskin, "Modelling of progressive and instantaneous failures of foliated rock slopes," Rock Mechanics and Rock Engineering, vol. 40, no. 4, pp. 349-362, 2007.

[13] M. Amini, A. Majdi, and Ö. Aydan, "Stability analysis and the stabilisation of flexural toppling failure," Rock Mechanics and Rock Engineering, vol. 42, no. 5, pp. 751-782, 2009.

[14] A. Carpinteri and M. Paggi, "Size-scale effects on strength, friction and fracture energy of faults: a unified interpretation according to fractal geometryfied interpretation according to fractal geometry," Rock Mechanics and Rock Engineering, vol. 41, no. 5, pp. 735-746, 2008.

[15] L.-g. Wang and X.-x. Miao, "Numerical simulation of coal floor fault activation influenced by mining," Journal of China University of Mining and Technology, vol. 16, no. 4, pp. 385-388, 2006.

[16] X. Li, S. J. Wang, T. Y. Liu, and F. S. Ma, "Engineering geology, ground surface movement and fissures induced by underground mining in the Jinchuan Nickel Mine," Engineering Geology, vol. 76, no. 1-2, pp. 93-107, 2004.

[17] L. J. Donnelly, "A review of coal mining induced fault reactivation in Great Britain," Quarterly Journal of Engineering Geology and Hydrogeology, vol. 39, no. 1, pp. 5-50, 2006.

[18] L. J. Donnelly, "A review of international cases of fault reactivation during mining subsidence and fluid abstraction," Quarterly Journal of Engineering Geology and Hydrogeology, vol. 42, no. 1, pp. 73-94, 2009.

[19] S. I. Sherman, "Natural triggers in violating the fault-andblock crust metastability in real time," Journal of Mining Science, vol. 45, no. 5, pp. 438-451, 2009.

[20] Z. Haijun, M. Fengshan, X. Jiamo, G. Jie, and Y. Guangxiang, "Experimental investigations of fault reactivation induced by slope excavations in China," Bulletin of Engineering Geology and the Environment, vol. 73, pp. 891-901, 2014.

[21] J. M. Xu, X. Li, and B. C. Han, "Original state of strain energy in a rock mass and its effect on excavation-induced displacement fields," International Journal of Rock Mechanics and Mining Sciences, vol. 25, no. 12, pp. 2467-2474, 2006.

[22] J. H. Zhang, Z. Y. Chen, and X. G. Wang, "Centrifuge modeling of rock slopes susceptible to block toppling," Rock Mechanics and Rock Engineering, vol. 40, no. 4, pp. 363-382, 2007.

[23] Z. X. Zhang, Y. Xu, P. H. S. W. Kulatilake, and X. Huang, "Physical model test and numerical analysis on the behavior of stratified rock masses during underground excavationfied rock masses during underground excavation," International Journal of Rock Mechanics and Mining Sciences, vol. 49, pp. 134-147, 2012.

[24] Q. Wu, M. Wang, and X. Wu, "Investigations of groundwater bursting into coal mine seam floors from fault zonesfloors from fault zones," International Journal of Rock Mechanics and Mining Sciences, vol. 41, no. 4, pp. 557-571, 2004. 